\title{
Stomach Contents of Great Horned Owl
}

\author{
by Robert Connell, University of Sask., Saskatoon*
}

Measured against the code of the sportsman and farmer, the sins of the Great Horned Owl are many. Over the years, man has been much against this bird, but still, throughout all months of the year, it remains the commonest and most numerous of all the large raptorial birds in these parts. The ability to survive is due perhaps to its relatively large brain; for the Great Horned Owl ranks with the birds - parrots, woodpeckers, magpies, crows, ravens, and other owls-that have relatively large, complex brains (Portmann and Stingelin, 1961).

Over the period from July 1, 1958, to June 1, 1961, the carcasses of 86 Great Horned Owls were examined in the Veterinary Science Department at the University of Saskatchewan. Most of the specimens secured were collected by Mr. Keith Thue, Manager, Provincial Game Farm, Beaver Creek, Saskatchewan. In the winters of 1958-59 and 1959-60 the birds were numerous in the vicinity of the Game Farm, apparently attracted to the area by the game farm bird stock. In the winter of 1960-61 the owls were scarcer and only 10 specimens were taken.

The owl specimens received by the Veterinary Laboratory were examined for any and all scientific data that they might yield. However, only the data indicating the eating habits of the birds will be reported here.

\section{Methods Employed in Examining the Stomach Contents of Owls}

The stomach contents on removal were first examined for the presence of feathers. If feathers were present, a search was made for the bill, feet, and other identifying structures of the bird eaten. If found, feathers and bill were transferred to a dish of water, cleaned, and their structure and color noted. Often feathers served as the only means of identifying bird remains in owl stomachs, and a good knowledge of comparative feather chracteristics had first to be acquired in order to identify bird meals.

After the preliminary examination mentioned, the stomach contents were soaked in 20 per cent potassium hydroxide solution for a few hours to digest and dissolve hair, feathers, and soft tissues, leaving undissolved any bones present, along with insects, mites, seeds, and such matter. After digestion the liquefied stomach contents were strained through a very fine (100 mesh) copper screen. The residue on the screen was gently washed in a stream of tap water. When clean, the residue on the screen was washed into a flat-bottomed, clear glass dish. After settling, excess water was poured off, and the residue transferred to petri dishes for examination under the dissecting microscope.

Identification of small mammalian remains is not difficult when skulls and teeth are present, provided the worker has acquired a knowledge of skull and teeth characteristics in the different native species of small mammals. To facilitate making the identifications, we first prepared a key to the skulls and teeth of small mammals in Saskatchewan. Specific identification of bird remains is more difficult, but usually possible. Fleas, lice and mites were useful aids in identifying what had been eaten. When an owl captures a small bird or mammal, it gulps it down immediately. External parasites on the prey are swallowed with it and can be found in the stomach contents. When the prey is larger, a rabbit for example, or a crow or chicken, the owl lays its prey open after a technique very similar to that which a veterinarian uses in conducting an autopsy on a chicken or small mammal. Consequently with larger prey, external parasites often crawl or hop off the prey on to the owl and are to be found on the bird's body.

For the reason just mentioned, each owl specimen secured in the field was immediately placed in a paper bag. The top of the bag was tied with a string or wire to keep external parasites from leaving the specimen. In the laboratory, the bags were opened. Before a bird specimen was

* Director, Veterinary Science Department, College of Agriculture. 
opened to remove the stomach, it was first taken out of the bag and placed in a container for about 10 minutes with a ball of cheesecloth saturated with ether. This anaesthetized the external parasites, which were then brushed out of the feathers on to a piece of paper and saved for identification. The bags were torn open and any parasites found crawling on the paper inside were collected and saved. I might add that external parasites stay alive for at least a week on carcasses in paper bags placed in a refrigerator.

\section{Results}

Fifty of the 86 owls examined yielded no information whatsoever to indicate what may have made up meals recently eaten. Data on each of the remaining 36 owls is shown in the table below.

Prey eaten by each of 36 Great Horned Owls as indicated by examination of of stomach contents and in a few cases, ectoparasites.

\begin{tabular}{|c|c|}
\hline Sex & Stomach Contents \\
\hline $\begin{array}{l}\text { Male } \\
\text { Female } \\
\text { Male }\end{array}$ & $\begin{array}{l}\text { Two red-backed voles. } \\
\text { One deer mouse, one red-backed vole. } \\
\text { Stomach contents not in themselves identifiable. Seven mouse } \\
\text { fleas were identified, indicating that the last meal had been } \\
\text { on mice. }\end{array}$ \\
\hline Male & Pheasant. \\
\hline Male & One red-backed vole. \\
\hline Male & Gray Partridge. \\
\hline ale & Six deer mice. \\
\hline $\begin{array}{l}\text { Male } \\
\text { Male }\end{array}$ & $\begin{array}{l}\text { One deer mouse. } \\
\text { Pheasant }\end{array}$ \\
\hline & One deer mouse. \\
\hline le & Jack rabbit. \\
\hline Female & Two pocket mice, one deer mouse, domestic chicken. \\
\hline Male & Stomach empty, but numerous fleas (Faxella ignota albertensis) \\
\hline Female & One deer mouse. \\
\hline Female & Two deer mice, one pygmy shrew. \\
\hline $\begin{array}{l}\text { Male } \\
\text { Female }\end{array}$ & One deer mouse. \\
\hline Male & $\begin{array}{l}\text { Une house mouse, one deer mouse, one red-backed vole. } \\
\text { One pocket gopher. }\end{array}$ \\
\hline Female & Four deer mice. \\
\hline Female & One deer mouse. \\
\hline Male & $\begin{array}{l}\text { Crow. } \\
\text { One deer mouse. }\end{array}$ \\
\hline Female & $\begin{array}{l}\text { Jack rabbit. A considerable number of crow lice were found on } \\
\text { this owl, suggesting that it had recently eaten a crow. However, } \\
\text { this surmise may be in error. Nesting owls regularly use old } \\
\text { crow nests and Holland }(1954) \text { suggests that the crow flea } \\
\text { hibernaites over-winter in abandoned crow nests. }\end{array}$ \\
\hline Female & Two red-backed voles, one Hairy Woodpecker. \\
\hline Female & Three pygmy shrews. \\
\hline Fema & Least chipmunk. \\
\hline Femá & $\begin{array}{l}\text { Stomach contents not in themselves identifiable, but red squir- } \\
\text { rel fleas were found, indicating that a red squirrel had been } \\
\text { eaten. }\end{array}$ \\
\hline Male & Two field mice. \\
\hline Male & Crow. \\
\hline Female & One pocket mouse. \\
\hline Male & Two deer mice. \\
\hline Female & Three deer mice. \\
\hline $\begin{array}{l}\text { Fem } \\
\text { Male }\end{array}$ & One deer mouse. \\
\hline Male & One field mouse (meadow vole). \\
\hline
\end{tabular}




\section{Discussion and Conclusion}

In discussing the economic status of the Great Horned Owl, Taverner (1934) recorded that of 110 stomachs examined, 31 contained poultry or game birds, 8 other birds, 13 mice, 65 other mammals, a scorpion, one fish, and 10 insects. Taverner considered this evidence against the owl. On the other hand, Brandt (1951) recorded that the commonest food constituents in the nests of this bird were cottontail rabbits, other small mammals, and occasionally birds. It would appear that the economic status of the Great Horned Owl, as Taverner says, "depends upon where it lives." An editorial note in the Blue Jay (18:16) mentions that Great Horned Owls in Montana were found to feed magpies to their young, and consequently were beneficial in controlling magpies.

Of the 36 owls that yielded data in this study, only one had eaten poultry, three had taken game birds, and one a Hairy Woodpecker. Thirtyone of the birds had taken no food that could in any way be regarded as economically useful to man. Of the 36 total, 29 had foraged successfully after mice, pocket gophers and crows, creatures that man regards as economically harmful. The only conclusion that I can draw from the data presented is that the Great Horned Owl, economically, is decidedly more beneficial than harmful.

\section{LITERATURE CITED}

BRANDT. H. 1951. Arizona and its bird life. The Bird Research Foundation, Cleveland, Ohio.

HOLLAND, G. P. 1954. The Crow Flea (Cerotophyllus rossittensis, Dampf, in North America (Siphonaptera Ceratophyllidae). The Canadian Entomologist, 86:334-336.

PORTMAN, $A$. and $W$. STINGELIN. 1961. The cortrol ne:vous system. Ch. XIII of Biology and comparative physiology of birds, ed. by A. J. Marshall. New York. Academic Press. TAVERNER, P. A. 1934. Birds of Canada. King's Printer, Ottawa.

\section{Common Tern Recovery From Cook Islands}

\section{by C. Stuart Houston, Saskatoon}

Although the Common Tern (Sterna hirundo) is known to winter at New Guinea and the Solomon Islands in the southwest Pacific these birds are presumed to have migrated from northeastern Asia (Kamchatka to Sakhalin Islands). There were apparently no specimens or sight records from the central Pacific until this past year when two banding recoveries were obtained.

On November 26, 1960, a bird wearing band 523-60398 was found in the lagoon near the beach at Ureia, Aitutaki Island, in the Cook Islands group administered by New Zealand. The band was found by Roi Marama and shown to Mr. P. Pamatatau of the Resident Agent's Office of the Cook Islands Administration, who reported it to the U.S. Fish and Wildlife Service, Washington, D.C. Unfortunately the band was not submitted and was lost by Mr. Marama in the several months that elapsed before my letter requesting the band could reach him. However, Mr. Pamatatau assured me that "It is proved correct by me and other official persons that the in- scription on the band is correct unless one figure is wrong which should be 525-60398 instead of 523-60398." (Note: 525 indicates a size 5 band and 523 a size 3 ). I then sent $\mathrm{Mr}$. Pamatatau sample bands of size 3 and size 5 to enquire which size the band was-he returned these with the inscription "this is it" opposite the size 3 band and "this is NOT" beside the size 5 band. Since there is a marked difference in size between a size 3 and size 5 band, there seems little doubt that it was the former. 523-60398, a nestling Common Tern, was banded by the writer at $51^{\circ} 21^{\prime} \mathrm{N}$., $105^{\circ} 15^{\prime} \mathrm{W}$., Last Mountain Lake, eight miles east of Imperial, Sask., on July 8, 1956.

The Cook. Islands are approximately 1800 miles northeast of New Zealand and between 2800 and 3000 miles south of the Hawaiian islands. The distance from Saskatchewan to the Cook Island is about 6000 miles. This is the farthest distance travelled by any of the 1134 recoveries received to date from over 20,000 birds banded by the writer. Of 350 Com- 